\title{
THE IMPACT OF INCIDENTAL AND INTENTIONAL L2 VOCABULARY LEARNING ON DEPTHS AND BREADTH DIMENSIONS OF VOCABULARY KNOWLEDGE
}

\author{
Seyyed Rasool Mirghasempour Ahmadi \\ Allameh Mohaddes Nouri University, Noor, Iran \\ rasoolmirghasempoor@gmail.com
}

\section{ABSTRACT}

Through the introduction of different dimensions of vocabulary knowledge, various studies have attempted to examine numerous effective factors on these dimensions. The present study aimed to show the effects of different vocabulary learning styles through extensive and intensive reading programs on depth and breadth aspects of vocabulary knowledge. To achieve this goal, 45 sophomore undergraduate students of English language teaching and translation in Payam-e-Noor University participated in this study. Initially, in order to homogenize the learners based on their level of language proficiency, MEPT was administered. Then, by measuring the mean and standard deviation of participants' scores, the number of participants was reduced to 35 . The ultimate subjects' scores on the reading comprehension items of MEPT show that they are all at the intermediate level of reading ability. Participants were divided into three experimental groups randomly: two groups were in the extensive reading program with different form-focused and meaning-focused tasks as incidental vocabulary learning style. And the third group was in the intensive reading program as intentional vocabulary learning style. Participants in these experimental groups read long stories or passages each week with ten goal-oriented words. After 8 weeks, the Word Associates Test (WAT) and Vocabulary Knowledge Scale (VKS) were administered to measure the acquired knowledge of new words and also, determining the effects of various learning styles on different dimensions of vocabulary knowledge. The results of Paired-samples and Independent T-tests revealed that both incidental and intentional groups developed in the period between the pre- and post-test, but, there was a significant difference between the effects of incidental vocabulary learning in the form of ER program and intentional vocabulary learning in the form of IR program. Moreover, there was a significant difference between the effects of the form-focused and meaning-focused task.

Keywords: Vocabulary knowledge, Incidental/Intentional learning, Intensive/Extensive reading 


\section{INTRODUCTION}

Vocabulary knowledge has a significant role in SLA (Schmidt, 2008). However, several factors can affect vocabulary learning (de Groot, 2006) such as the degree of involvement (Hulstijn \& Laufer, 2001), repetition and usage of the words, and the most important; the way of acquisition. Hence, finding the most beneficial way to promote vocabulary knowledge and improve direct instruction of foreign language vocabulary have become main issues in the domain of foreign language teaching and learning (Kawauchi, 2005).

Reading is one of the most valuable and encouraging skills in SLA and serves as an important way to learn new foreign language vocabularies. This skill helps language learners in their vocabulary learning in two ways: first, learners while reading new texts will find out that there are some words which they do not know their meanings. So, it motivates learners and spurs their curiosity to look up these words in their dictionaries and the final outcome will be broad vocabulary knowledge. Second, reading is an effective tool for recalling and retention of previously memorized words which provides more mental capacity for learning new words. These two notable characteristics of reading make it more appealing and enjoyable for foreign language learners.

Two different approaches were suggested for reading: Extensive Reading (ER) and Intensive Reading (IR). Each one of these pursues different ways to achieve the same goal, that is, SLA by enhancing vocabulary knowledge. However, this twin categorization is regarded as the most well-known dichotomy and can be found in most resource books for learners and instructors but this is not the whole story for them. Extensive and Intensive readings are well-known representatives for incidental and intentional learning, respectively. Extensive reading is an approach in which learners are free to select and read various texts and books which are guided by teachers (Day \& Bamford, 1998; Prowse, 1999). The main purpose of this approach is to improve learners reading habit through increasing learners' joy of reading and also improving their comprehension without using dictionaries (Day \& Bamford, 1998). Therefore, by improving learners' exposure to the L2, their level of language proficiency will be increased. In contrary, Intensive reading has quite a different story. In this approach, learners read different fairly complicated texts in L2 in order to improve their knowledge and obtain more information. Thereby, in an intensive approach, both the rate and joy level of reading are lower. Various studies were carried out to investigate the relationship between vocabulary knowledge and reading skill. Most of these studies placed emphasis on the effectiveness and benevolent role of extensive reading on vocabulary knowledge (Pigada \& Schmidt, 2006; Rashidi \& Piran, 2011), but some studies have shown contradictory results, as extensive reading alone does not lead to vocabulary acquisition (Paribakht \& Wesche, 1997; Green, 2005). 


\section{REVIEW OF LITERATURE}

\subsection{Incidental and Intentional Vocabulary Acquisition}

One of the subcategories of implicit-explicit dichotomy is incidental and intentional learning. These two perspectives of learning are contradictory but somehow complementary. There are various ways in which the terms "incidental learning" and "intentional learning" were defined and then used. This article reviews these notions in two prominent aspects, namely the psychological and L2 learning literature.

The origins of the notions of incidental and intentional learning are in the field of psychology. Initially, the appearance of these two notions occurred in the era of stimulus-response (S-R) psychology, that is, the conditional learning period. After the introduction of $\mathrm{S}-\mathrm{R}$ associations (associationforming) in learning, different researchers tried to evaluate this theory in learning. Therefore, different sorts of conditional learning ranging from elementary to complex forming of associations (Gagne, 1965) were examined. Signal learning is the most elementary form of conditional learning and L1-L2 word pairs is an example of stimulus-response pairing which is a sample of complex conditional learning. For three decades, from the 1940s to 1960s, psychologists try to develop a theory of learning which keep motivated the learners and must be both theoretically acceptable and operationally applicable. Scholars commenced working on a concept merely in terms of the presence or absence of an explicit instruction to learn. The central point in this new concept was whether or not participants are told in advance that they will be tested, that is, intentional or incidental learning.

In a second context, Horst et al. (1998) examined the existence of incidental vocabulary learning and also, the superiority of intentional learning to incidental learning among 34 low-intermediate ESL learners in Oman. The results indicated that the power of incidental L2 vocabulary learning may have been overestimated previously.

With the introduction of cognitive psychology in the 1960s and 1970s and decline of conditional psychology, the constructs of incidental and intentional learning were going to be deceased. But some of the cognitive psychologists by changing incidental and intentional learning methodological procedures and keeping their theoretical framework opened a new window to these concepts. For instance, Hyde and Jenkins (1973) presented groups of participants with a number of words and asked each group to perform a different orienting task. Participants did not forewarn that they would be later tested on their recall of the words. Researchers demonstrated that retention on the unexpected test fluctuated with the orienting task.

The notions of incidental and intentional learning into L2 learning literature began prominently in one domain but not the others, i.e. incidental and intentional learning investigates mainly in the area of vocabulary learning and only exceptionally in the area of grammar. They do not appear at all in the areas of phonology and phonetics. 
Generally speaking, learning is characterized intentional when participants are forewarned that they will be tested on the material to which they are exposed and is considered incidental when participants are not expecting a memory test (Mantyla, 2001). Different researchers propose different definitions for incidental and intentional learning. One of the eminent researchers in this domain is Schmidt (1994a) suggesting various definitions of incidental and intentional learning and one of the most straightforward his definition of incidental learning is "learning one thing (...) when the learners' primary objective is to do something else (...)" (p. 16). He also defined intentional learning as a kind of learning in which "learners have the explicit intention of learning and retaining lexical information by using the rehearsal and memorizing techniques" (Schmidt, 1997). After Schmidt, Gass (1999) recommended her elaborated meaning for incidental learning as the learning of grammatical structures without exposure to the samples of these structures.

Wode (1999) carried out a pilot study of incidental learning of productive vocabulary with a duration of seven months in a grade seven immersion program in a German high school that is, using English as their L2 and German as their L1. In this study, one immersion class which had, one subject taught in English that provides an extensive reading for students, in addition to regular English-as-a-subject lessons, was compared with two control groups. Wode reported that immersion (experimental) group in a post-test "used a considerably larger vocabulary than the two control groups in terms of both types and tokens" (p. 249).

Pitts et al. (1989) examined two groups of ESL learners who read two chapters of A Clockwork Orange, containing 241 unfamiliar words. Participants did not know that these unfamiliar words would be tested later; instead, they were told that they would be given a comprehension and literary criticism test. By testing participants' understanding of these unknown words, small vocabulary growth was reported relative to control group who had not read the text. So, the researchers stated that L2 learners can acquire vocabulary by reading.

\subsection{Depth vs. Breadth dimensions of word knowledge}

Just till the recent decade, language teachers in their way of instructing new words merely focused on the number and the frequency of the words in the target language. But regarding Qian's (1999) proposal, vocabulary knowledge is considered modular but not unitary. And it is comprised of two dimensions: breadth (size) and depth of vocabulary knowledge (Paribakht \& Wesche, 1996, Milton, 2009). Qian (2002) states that vocabulary learning happens in a slow and incremental manner, that is, vocabulary learning is a life-long process. So, learners cannot boost that they can learn all vocabularies of a language in a specified period of time. This claim also emphasizes on the depth dimension of vocabulary learning, which denotes the fact that the sooner an item is memorized, the easier the learner recalls this word. 
Moreover, Qian (2002) characterizes the importance of learners' breadth dimension of vocabulary knowledge, he stresses the significance of depth of vocabulary knowledge as a means by which learners can improve their guessing skill of the meaning of unknown words in a context, thereby making the text comprehensible.

Breadth (size) of vocabulary knowledge as obvious by its name refers to the number of words that language learners know at a particular level of language proficiency (Nation, 2001). Several tools were proposed for measuring this dimension of vocabulary knowledge (Wesche \& Paribakht, 1996) but one the most frequent used measure according to Nassaji (2004) to appraise the size of vocabulary knowledge is Vocabulary Levels Test (VLT).

The depth of vocabulary knowledge is considered as for how well the language learner knows the word (Read, 1993, 2000). According to Nassaji (2004, p.112), researchers stressed that "knowing a word is something more than knowing its individual meaning in a specific context". So, the depth dimension of vocabulary knowledge is referred as the association of a word with various kinds of knowledge such as pronunciation, spelling, meaning, collocational meaning, register, frequency, syntactic, and stylistic and morphological properties (Haastrup \& Henriksen, 2000; Read, 2000). These properties are not isolated but each of these components interacts with each other constantly to improve the total level of the depth dimension of vocabulary knowledge, therefore produce the maximum comprehension of the text. Opposing the broadly available tools for assessing the breadth dimension of vocabulary knowledge, the means for measuring depth dimension of vocabulary knowledge is very narrow and only is limited to Word Associations Test (WAT) that was developed by Read (1993, 1998, 2000). He designed this test for measuring learners' depth dimension of vocabulary knowledge through three fundamental relationships among words, namely paradigmatic, syntagmatic, and analytic (Read, 2004, p.221).

In spite of the fact that, the arrival of depth and breadth dimensions of vocabulary knowledge in the field of L2 learning is new, but it is in the limelight of academic literature recently. Several studies can be found in the literature of L2 learning which mainly focused on the relationship between depth and size dimensions of vocabulary knowledge and also, the relationship between learners' vocabulary knowledge and their subsequent learning of vocabulary through reading (Rashidi \& Piran, 2011; Yalli, 2010).

Qian (1999) examined a research on 44 Korean and 33 Chinese speakers through VLT and WAT and reached to the high level of intercorrelations between vocabulary size, depth of vocabulary knowledge, and reading comprehension, in the range of .78- .82. In another study, Nurweni and Read (1999) conducted a research on 350 EFL Indonesian college students to investigate the relationship between size and depth dimensions of vocabulary knowledge through word translation and word association tests. The overall correlation for this study was .62. But by dividing participants into three 
groups based on their level of language proficiency, two tests was correlated at $.81, .43$, and .18 for High, Middle, and Low groups, respectively.

\subsection{Extensive vs. Intensive Reading}

Reading is an elementary and complementary skill in language learning. Reading, as a receptive skill, is a highly complicated process and it requires the knowledge of correct pronunciation, word recognition, comprehension skills, and speed of reading as well as confidence on the part of the learner (Tangitau, 1973). Various definitions are presented for reading and one of the shortest definitions is attributed to Perfetti (1984, pp. 40-41) who defines learning as "thinking guided by print".

Two major subdivisions of reading are Intensive Reading (IR) and Extensive Reading (ER) which were coined by Mary Finnochiaro (1958). Finnochiaro $(1958$, p. 40$)$ defined these terms as "in Intensive reading as the term indicates, each vocabulary and the structural item are explained and made part of the student active language; pronunciation and intonation are stressed; each concept is clarified. In extensive reading, the principle aim is comprehension. Pupils are trained to get the meaning primarily from the context although some common vocabulary items may be developed for active use".

ER as one of the well-known approaches to teaching reading has been studied abundantly in the field of L2 learning and in the domain of L2 reading instruction (Yamashita, 2008). Numerous researchers along the past years depict successfully the significant role of ER in L2 reading by providing opportunities for learners to enhance their fluency in the areas of word recognition, vocabulary acquisition, and developing reading comprehension skills (Pigada \& Schmidt, 2006; Yamashita, 2008). In fact, various studies in this area have underlined the positive impact of ER on language proficiency in general and vocabulary development in particular (Horst, 2005). Some studies, however, did not show the direct effect of ER on vocabulary acquisition (Paribakht \& Wesche, 1997; Green, 2005). Besides, some researchers have claimed that teachers can improve their students' vocabulary knowledge efficiently by emphasizing on vocabulary-focused tasks, namely form-oriented and meaning-oriented tasks (Praibakht \& Wesche, 1997; Hustijn \& Laufer, 2001). These tasks are more demanding and increase the learners' involvement in their path of word processing, thereby better word retention and retrieval will be anticipated.

The goals of the current study are to investigate the effects of various vocabulary-focused tasks applying in an ER program in the form of incidental learning and in an IR program as intentional learning on depth and breadth dimensions of vocabulary knowledge and to compare the obtained results to reveal different effects of incidental and intentional learning on different dimensions of vocabulary knowledge. 


\section{RESEARCH QUESTIONS}

To investigate the effects of incidental and intentional vocabulary learning on both depth and breadth dimensions of vocabulary knowledge in an immediate post-test condition the following questions were addressed:

Q1. Does incidental learning affect EFL learners' depth and breadth dimensions of vocabulary knowledge?

Q2. Is there a significant difference between the effects of form-focused and meaning-focused tasks on EFL learners' vocabulary knowledge?

Q3. Does intentional learning affect EFL learners' depth and breadth dimensions of vocabulary knowledge?

Q4. Is there a significant difference between the effects of incidental and intentional learning on EFL learners' vocabulary knowledge?

\section{4METHODOLOGY}

\subsection{Research Design}

The present study employed a quasi-experimental design using a pretesttreatment-posttest procedure to collect data. This study had three experimental groups with no control group. Participants of this study were selected from two classes with the same teacher in order to reduce teacher effect.

\subsection{Participants and Setting}

To collect data, 45 sophomore undergraduate students, studying at Payame-Noor University of two classes with the same teacher in the course of reading comprehension (II) both males and females majoring in English language teaching and translation were selected randomly in this study. In order to homogenize the participants according to their level of language proficiency Michigan English Placement Test (MEPT) was administered. After the administration and calculating the mean and standard deviation of test's scores, the participants obtaining above and below the mean were omitted. So, the number of participants decreased to 35 (Males=17, Females $=18$ ). The performance of ultimate (remaining) participants on the reading section of MEPT showed that all of them were intermediate L2 readers, so their homogeneity in their reading skill was observed, too. Their ages range from 18 to 28 .

Participants were divided randomly into three groups: two groups of incidental learning with different vocabulary-focused tasks and one group of intentional learning. The first group of incidental learning was given a formfocused task (FFT) in their ER program, the second group of incidental learning was given a meaning-focused task (MFT) in their ER program while the third group involved in their IR program. The gender demographics of participants in different groups are presented below in Table 1. 
Table 1. The gender of participants

\begin{tabular}{|c|c|c|c|}
\hline Group & Gender & Frequency & Percent \\
\hline \multirow{2}{*}{ ER-FFT } & Male & 7 & 58.3 \\
\hline & Female & 5 & 41.7 \\
\hline \multirow{2}{*}{ ER-MFT } & Male & 5 & 41.7 \\
\hline & Female & 7 & 58.3 \\
\hline \multirow{2}{*}{ IR } & Male & 5 & 45.5 \\
\hline & Female & 6 & 54.5 \\
\hline
\end{tabular}

\subsection{Instruments}

\subsubsection{Michigan English Placement Test (MEPT)}

Michigan English Placement Test (MEPT) is a test of English language proficiency which consists of four different kinds of skills: listening comprehension, grammar, vocabulary, and reading comprehension. The test consists of 100 questions in the form of multiple-choice questions.

The listening section involves 20 items which categorized into two forms: "response evaluation and paraphrase recognition" (Buck, 2001).The grammar section contains 30 items which cover a wide range of grammatical structures including choosing an appropriate pronoun form, verb form, or word form, and etc. The vocabulary section includes 30 items. Test-takers are asked to answer the questions based on one or two short sentences. The reading section consists of 20 items. Each item differs in complexity and length and presents one question about the information in the sentence. The average length of the items in the reading section is about twenty words.

The reliability of this test obtaining by calculating the total odd and even scores is .753 (Wistner et al., 2009) and the results of factorial analysis of construct validity of subsections of the test show that the questionnaire has a high degree of validity (Wistner et al., 2009).

\subsubsection{Word Associates Test (WAT)}

Word associated test developed by Read (1993, 1998) through employing three parameters namely paradigmatic (meaning), syntagmatic (collocation) and polysemy was used to measure the intermediate learners' depth of vocabulary knowledge. The WAT includes 40 items; each item has eight options of four adjectives as its potential synonyms and four nouns as its possible collocations. Each item has always four correct choices. In scoring, each correct answer was awarded one point. The maximum possible score, thereby, was 160 for the forty items.

Qian (1999) showed that this test has a high degree of internal reliability. The reliability of the test as reported by Read is 0.93 and by Qian (1998, 2002) and Nassaji (2004) above 0.90. Different studies make clear that the 
test, moreover, having a high degree of correlation with the size of vocabulary knowledge, is closely correlated with L2 reading comprehension ability.

\subsubsection{Vocabulary Knowledge Scale (VKS)}

Vocabulary knowledge scale (VKS) was developed by Sima Paribakht and Mari Wesche (1996) for research on vocabulary learning in the context of vocabulary reading activities and also, the ability to infer the meaning of unknown words. VKS is a simple formal assessment that can be used to measure ongoing progress learning individual words (Paribakht \& Wesche, 1997). A VKS measures how well as well as how many words learners know to improve their word power and can use words on a rating scale. This rating scale was proposed by Paribakht and Wesche (1997) on a 5-point Likert-type scale and was used in the current study to score the VKS in the pre and posttests based on based on the following criteria:

I. One point was given to "I do not remember having seen this word before"

II. Two points were given to "I have seen this word before, but I do not know what it means"

III. Three points were given to "I have seen this word before, and I think it means ----- (synonym or translation)"

IV. Four points were given to "I know this word. It means ----(synonym or translation)",

V. Five points were given to "I can use this word in a sentence: --------. (Write a sentence.) (If you do this section, please also do section IV)"

The total score for each word is 15 , that is, scores must be added up. For example, if a participant can use a word correctly both syntactically and semantically in a sentence, he/she was given $(1+2+3+4+5) 15$. Or he/she is sure of the meaning of a word, he/she was given $(1+2+3+4) 10$. Read (2000) stated that this scale has some limitations such as being self-reporting, does not allow for a word having more than one meaning (homonym), etc.

The researcher used this test in pre- and post-test, according to following procedure; VKS as the pre-test was used to rate the words which learners wish to learn, including purpose words in addition of some distractors and was used as post-test (without including distractors), to measure learners' progress of vocabulary knowledge and understand to what degree the learners were able to learn the words in various experimental groups.

\subsection{Procedure}

Following procedures were carried out to achieve the objectives of the present study. 
First, in order to reach the homogeneity among the subjects based on their level of language proficiency, MEPT was carried out. 45 participants were tested on MEPT and by measuring the standard deviation and mean of the subjects' scores, 35 subjects were selected. They were at the intermediate level of language proficiency and their scores on comprehension reading items on MEPT revealed that their level of comprehension reading proficiency was intermediate, too.

Second, two standardized test were used as a pre-test for measuring the breadth and depth of subjects' vocabulary knowledge. This study used WAT which takes 30 minutes to complete for assessing subjects' depth of vocabulary knowledge. And the VKS containing the words the participants were supposed to learn accompanied with some distracters were given in the pre-test. Initial results of this test show that majority of the participants had not any background of the new words.

Third, all participants $(\mathrm{n}=35)$ of the current study were assigned randomly into three experimental groups namely two groups of incidental learning of extensive reading program by different tasks (meaning- and form-focused tasks) and one group of intensive reading as intentional learning.

The first group $(\mathrm{n}=12)$ did a form-focused task in which subjects required to read a story (3000-5000 words) per session before the class and to prepare a notebook involving list of unknown words with their dictionary definitions, collocations, writing one example presented in the dictionary and one example of their own, and the sentences they located the words in. The second group $(\mathrm{n}=12)$ performed a meaning-focused task in which participants asked to read a story (3000-5000 words) per session before the class. Then, they presented orally the stories to the class and shared their opinions and ideas about the stories with their classmates. Finally, answer some questions and exercises of the stories. Subjects had approximately fifteen minutes to carry out their tasks such as providing a summary and asking questions. The last group (intentional reading group) did an intensive reading. They read some passages in the class which contain the words researcher wish to assess subjects' learning. In this group, the teacher provided definitions, meanings of words in the target language, synonyms, and antonyms for a limited number of words. Learners were asked to read, memorize, and review this limited number of words after the class and for next session teacher would ask some questions about the words randomly.

The treatments for all three experimental groups being carried out by the same teacher for eight sessions and for measuring learning of sixty new words. Finally, WAT and VKS (this time without any distracter) were carried out as post-tests for assessing the effects of treatments on subjects learning depth and breadth of vocabulary knowledge. 


\subsection{Data Analysis and Results}

H01: Incidental vocabulary learning in the form of ER program doesn't affect EFL learners' depth and breadth dimensions of vocabulary knowledge.

In this part, research hypotheses were examined. To consider the effects of incidental learning on learners' depth and breadth dimensions of vocabulary knowledge, the paired samples $\mathrm{T}$-test was used to compare the scores of participants in ER program before and after the ER course. Table 2 shows the results of analysis of incidental vocabulary learning for both dimensions of the vocabulary knowledge.

Table 2. T-test statistics on the differences of depth and breadth of vocabulary knowledge for Incidental group

\begin{tabular}{|c|c|c|c|c|c|c|c|c|c|c|}
\hline \multirow{3}{*}{\multicolumn{2}{|c|}{ Group }} & & \multicolumn{5}{|c|}{ Paired Differences } & \multirow[t]{3}{*}{$\mathrm{t}$} & \multirow{3}{*}{$\mathrm{df}$} & \multirow{3}{*}{$\begin{array}{l}\text { Sig. } \\
(2- \\
\text { tailed })\end{array}$} \\
\hline & & & \multirow[t]{2}{*}{ Mean } & \multirow[t]{2}{*}{$\begin{array}{c}\text { Std. } \\
\text { Deviation }\end{array}$} & \multirow[t]{2}{*}{$\begin{array}{l}\text { Std. } \\
\text { Error } \\
\text { Mean }\end{array}$} & \multicolumn{2}{|c|}{$\begin{array}{c}95 \% \text { Confidence } \\
\text { Interval of the } \\
\text { Difference } \\
\end{array}$} & & & \\
\hline & & & & & & Lower & Upper & & & \\
\hline \multirow{3}{*}{ Incidenta } & & Pre-WAT & & & & & & & & \\
\hline & Pair 1 & $\begin{array}{l}\text { Post- } \\
\text { WAT }\end{array}$ & -17.95 & 9.79 & 1.99 & -22.09 & -13.82 & -8.98 & 23 & .000 \\
\hline & Pair 2 & $\begin{array}{l}\text { Pre-VKS } \\
\text { Post-VKS }\end{array}$ & -176.20 & 65.16 & 13.30 & -203.72 & -148.69 & -13.24 & 23 & .000 \\
\hline
\end{tabular}

The T-test analysis (Table 2) showed that the differences between preand post-tests for both depth (Mean= -17.95) and breadth (Mean= -176.20) dimensions of vocabulary knowledge were statistically significant. For depth dimension of vocabulary knowledge $(\mathrm{t}=-8.09, \mathrm{df}=23$, two-tailed $\mathrm{P}<\alpha)$, because the $\mathrm{P}$ value (.00) was lower than .05 ; therefore, the null hypothesis was rejected. Moreover, for breadth dimension of vocabulary $(\mathrm{t}=-13.24, \mathrm{df}=$ 23 , two-tailed $\mathrm{P}<\alpha$ ), because the $\mathrm{P}$ value (.00) was lower than .05; therefore, the null hypothesis was rejected. It was concluded that Incidental vocabulary learning in the form of ER program has a significant effect on depth and breadth dimensions of participants' vocabulary knowledge.

H02: There isn't a significant difference between the effects of formfocused and meaning-focused tasks on EFL learners' depth and breadth dimensions of vocabulary knowledge.

To examine the second question and investigate whether there is a significant difference between the effects of form-focused and meaning-focused tasks in the ER program on participants' depth and breadth dimensions of lexical knowledge, an independent T-test was administered. Table 3 shows the results of 
analysis of the effects of FFT and MFT for both dimensions of the lexical knowledge.

\begin{tabular}{|c|c|c|c|c|c|c|c|c|c|c|}
\hline & & \multicolumn{2}{|c|}{$\begin{array}{c}\text { Levene's Test } \\
\text { for Equality of } \\
\text { Variances }\end{array}$} & \multicolumn{7}{|c|}{ t-test for Equality of Means } \\
\hline & & \multirow[t]{2}{*}{$\mathrm{F}$} & \multirow[t]{2}{*}{ Sig. } & \multirow[t]{2}{*}{$\mathrm{t}$} & \multirow[t]{2}{*}{$\mathrm{df}$} & \multirow[t]{2}{*}{$\begin{array}{l}\text { Sig. } \\
(2- \\
\text { tailed) }\end{array}$} & \multirow[t]{2}{*}{$\begin{array}{c}\text { Mean } \\
\text { Differen } \\
\text { ce }\end{array}$} & \multirow[t]{2}{*}{$\begin{array}{l}\text { Std. } \\
\text { Error } \\
\text { Differe } \\
\text { nce }\end{array}$} & \multicolumn{2}{|c|}{$\begin{array}{c}95 \% \\
\text { Confidence } \\
\text { Interval of the } \\
\text { Difference }\end{array}$} \\
\hline & & & & & & & & & Lower & Upper \\
\hline \multirow{2}{*}{$\begin{array}{l}\text { Post- } \\
\text { WAT }\end{array}$} & $\begin{array}{c}\text { Equal } \\
\text { variances } \\
\text { assumed }\end{array}$ & .56 & .46 & 6.0 & 22 & .000 & 10.5 & 1.7 & 6.8 & 14.1 \\
\hline & $\begin{array}{c}\text { Equal } \\
\text { variances } \\
\text { not assumed }\end{array}$ & & & 6.0 & 21.6 & .000 & 10.5 & 1.7 & 6.8 & 14.1 \\
\hline \multirow{2}{*}{$\begin{array}{l}\text { Post- } \\
\text { VKS }\end{array}$} & $\begin{array}{c}\text { Equal } \\
\text { variances } \\
\text { assumed }\end{array}$ & .84 & .36 & 4.9 & 22 & .000 & 74.2 & 15.0 & 43.1 & 105.3 \\
\hline & $\begin{array}{c}\text { Equal } \\
\text { variances } \\
\text { not assumed }\end{array}$ & & & 4.9 & 21.6 & .000 & 74.2 & 15.0 & 43.0 & 105.4 \\
\hline
\end{tabular}

Table 3. T-test statistics on the differences of depth and breadth dimensions of vocabulary knowledge between FFT and MFT groups in posttest scores.

Table 3 shows that depth and breadth dimensions' significance are.00; therefore, the $\mathrm{P}$ value is lower than $\alpha(.05)$. As a result, there were statistically significant differences between the mean scores of the FFT and MFT on the depth and breadth dimensions of lexical knowledge. It means that FFT group performed better than MFT group on both depth and breadth dimensions of lexical knowledge because the mean differences are positive (Depth's Mean Difference $=10.5$, Breadth's Mean Difference $=74.2$, that is, $\mu 1-\mu 2>0$ ).

H03: Intentional vocabulary learning in the form of IR program doesn't affect EFL learners' depth and breadth dimensions of vocabulary knowledge.

To investigate the effects of intentional learning on learners' depth and breadth dimensions of vocabulary knowledge, the paired samples T-test was used to compare the scores of participants in IR program before and after the IR course. Table 4 shows the results of analysis of intentional vocabulary learning for both dimensions of the vocabulary knowledge. 
Table 4. T-test statistics on the differences of depth and breadth of vocabulary knowledge for Intentional group

\begin{tabular}{|c|c|c|c|c|c|c|c|c|c|}
\hline \multirow{5}{*}{\multicolumn{3}{|c|}{ Group }} & \multicolumn{5}{|c|}{ Paired Differences } & \multirow{5}{*}{\multicolumn{2}{|c|}{$\begin{array}{r}\mathrm{t} \text { df } \begin{array}{l}\text { Sig. } \\
\text { tailed) }\end{array} \\
\end{array}$}} \\
\hline & & & \multirow[t]{4}{*}{ Mean } & \multirow{4}{*}{$\begin{array}{c}\text { Std. } \\
\text { Deviation }\end{array}$} & \multirow{4}{*}{$\begin{array}{l}\text { Std. } \\
\text { n Error } \\
\text { Mean }\end{array}$} & \multirow{3}{*}{\multicolumn{2}{|c|}{$\begin{array}{c}95 \% \\
\text { Confidence } \\
\text { Interval of the } \\
\text { Difference }\end{array}$}} & & \\
\hline & & & & & & & & & \\
\hline & & & & & & & & & \\
\hline & & & & & & Lower & Upper & & \\
\hline \multirow{4}{*}{ Intensive } & \multicolumn{3}{|c|}{ Pre-WAT } & & & & & & \\
\hline & Pair 1 & Post- & -27.72 & 9.88 & 2.97 & -34.36 & -21.08 & -9.3010 & .000 \\
\hline & & WAT & & & & & & & \\
\hline & \multicolumn{2}{|c|}{ 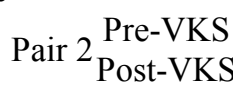 } & -268.63 & 57.50 & 17.33 & -307.26 & -230.02 & -15.4110 & .000 \\
\hline
\end{tabular}

The T-test analysis (Table 4) showed that the differences between preand post-tests for both depth (Mean= -27.72) and breadth (Mean= -268.63) dimensions of vocabulary knowledge were statistically significant. For depth dimension of vocabulary knowledge $(\mathrm{t}=-9.30, \mathrm{df}=10$, two-tailed $\mathrm{P}<\alpha)$, because the $\mathrm{P}$ value (.00) was lower than .05 ; therefore, the null hypothesis was rejected. Moreover, for breadth dimension of vocabulary $(\mathrm{t}=-15.41, \mathrm{df}=$ 10 , two-tailed $\mathrm{P}<\alpha$ ), because the $\mathrm{P}$ value (.00) was lower than .05 ; therefore, the null hypothesis was rejected. It was concluded that Intentional vocabulary learning in the form of IR program has a significant effect on depth and breadth dimensions of participants' vocabulary knowledge.

H04: There isn't a significant difference between the effects of incidental and intentional learning on EFL learners' depth and breadth dimensions of vocabulary knowledge.

To investigate the fourth question and consider whether there is a significant difference between the effects of incidental vocabulary learning in the form of ER program and intentional vocabulary learning in the form of IR program on participants' depth and breadth dimensions of lexical knowledge, an independent $\mathrm{T}$-test was administered. Table 5 shows the results of analysis of the effects of incidental and intentional vocabulary learning for both dimensions of vocabulary knowledge. 
Table 5. T-test statistics on the differences of depth and breadth dimensions of vocabulary knowledge between Incidental and Intentional groups in post-test scores

\begin{tabular}{|c|c|c|c|c|c|c|c|c|c|}
\hline & & \multicolumn{2}{|c|}{$\begin{array}{c}\text { Levene's } \\
\text { Test for } \\
\text { Equality } \\
\text { of } \\
\text { Variances }\end{array}$} & \multicolumn{6}{|c|}{ t-test for Equality of Means } \\
\hline & & \multirow[t]{2}{*}{$\mathrm{F}$} & \multirow[t]{2}{*}{ Sig. } & \multirow[t]{2}{*}{ df } & \multirow[t]{2}{*}{$\begin{array}{l}\text { Sig. } \\
(2- \\
\text { tailed })\end{array}$} & \multirow[t]{2}{*}{$\begin{array}{c}\text { Mean } \\
\text { Differe } \\
\text { nce }\end{array}$} & \multirow{2}{*}{$\begin{array}{c}\text { Std. } \\
\text { Error } \\
\text { Differe } \\
\text { nce }\end{array}$} & \multicolumn{2}{|c|}{$\begin{array}{c}95 \% \text { Confidence } \\
\text { Interval of the } \\
\text { Difference }\end{array}$} \\
\hline & & & & & & & & Lower & Upper \\
\hline \multirow{2}{*}{$\begin{array}{l}\text { Post- } \\
\text { WAT }\end{array}$} & $\begin{array}{c}\text { Equal } \\
\text { variances } \\
\text { assumed }\end{array}$ & .6 & .43 & $-3.6 \quad 33$ & .001 & -9.6 & 2.6 & -14.9 & -4.3 \\
\hline & $\begin{array}{c}\text { Equal } \\
\text { variances } \\
\text { not assumed }\end{array}$ & & & -3.416 .8 & .003 & -9.6 & 2.7 & -15.5 & -3.7 \\
\hline \multirow{2}{*}{$\begin{array}{l}\text { Post- } \\
\text { VKS }\end{array}$} & $\begin{array}{c}\text { Equal } \\
\text { variances } \\
\text { assumed }\end{array}$ & 4.0 & .05 & -5.633 & .000 & -96.5 & 17.04 & -131.1 & -61.8 \\
\hline & $\begin{array}{c}\text { Equal } \\
\text { variances } \\
\text { not assumed }\end{array}$ & & & -6.830 .6 & .000 & -96.5 & 14.13 & -125.3 & -67.6 \\
\hline
\end{tabular}

Table 5 shows that depth and breadth's significances are .001 and .000 , respectively. Therefore, for both dimensions of vocabulary knowledge, the $\mathrm{P}$ value is lower than $\alpha(.05)$. As a result, there were statistically significant differences between the mean scores of incidental and intentional learning for both dimensions of vocabulary knowledge. It means that intentional group performed better than incidental group on the depth and breadth dimensions of lexical knowledge, because the mean differences for both dimensions are negative (Depth's Mean Difference= -9.6; Breadth's Mean Difference= -96.5; that is, $\mu 1-\mu 2<0$ )

\section{DISCUSSIONS AND CONCLUSIONS}

In this article, the researcher attempted to investigate the effects of incidental and intentional learning on size and depth of vocabulary knowledge through various reading programs. For measuring the effects of incidental learning, the researcher adopted ER program with two different tasks and for evaluating the effects of intentional learning, IR program was adopted. The subjects were randomly assigned in ER or IR program. At the first phase, the findings of the present study indicated that vocabulary learning in the form of incidental and intentional learning with form focused and meaning-focused 
tasks led to some developments of vocabulary knowledge. These findings are in keeping with the findings of other studies (e.g. Khnoamri \& Roostaee, 2013; Maghsoudi et al, 2014) which showed that both incidental and intentional learning through FFT or MFT can make some enhancement in learners' lexical knowledge. But at the second phase, it was an intentional group that performs better in word memorizing and retention than the incidental group. This result is in contrast to the findings of the previous studies which emphasized that incidental learning in the form of ER program could be fully incorporated into the EFL language program in which exposure to the target language can be provided to the learners through their engagement in extensive reading (Khonamri \& Roostaee, 2013). However, most of the studies overestimated the effectiveness of incidental learning, but some other studies suggest that incidental learning alone may not be sufficient in assisting learners to promote their vocabulary knowledge (e.g., Kasahara, 2011).

The findings illuminate the importance of several factors in vocabulary teaching/learning: firstly, learners' levels of proficiency must be considered in order to prescribe the most beneficial model of vocabulary learning, because in lower and even in some intermediate level learners cannot benefit of compensation strategies (e.g., guessing) in their path of vocabulary learning, hence the vast amount of unknown information and incapability in processing them may overwhelm learners. Secondly, the context (ESL/EFL) and purpose of language learning are important. Sometimes learners have an integrative and sometimes instrumental orientation; hence, their purpose will determine their mode of study and learning. Finally, it is highly suggested that curriculum designers and teachers consider the findings of this study to approach a better practice in vocabulary learning.

\section{REFERENCE}

Buck, G. (2001). Assessing listening. Cambridge University Press.

Day, R., \& Bamford, J. (1998). Extensive reading in the second language classroom. Cambridge University Press.

De Groot, A. M. D. (2006). Handbook of bilingualism: Psycholinguistic Approaches. Oxford: Oxford University Press.

Finnochiaro, M. (1958). Teaching English as a Second Language. New York: Harper and Brothers.

Gass, S. (1999). Incidental vocabulary learning: Discussion. Studies in Second Language Acquisition, 21(3), 19-333.

Grabe, W., \& Stoller, F. (1997). Reading and vocabulary development in a second language: A case study. In J. Green, C. (Eds.), Integrating extensive reading in the task-based curriculum (PP. 306-311). Oxford University Press.

Green, D. W. (2005). The Neurocognition of Recovery Patterns in Bilingual Aphasics. Oxford University Press, 516-530.

Haastrup, K., \& Henriksen, B. (2000). Vocabulary acquisition: acquiring depth of knowledge through network building. International Journal of Applied Linguistics, 10, 221-240. 
Horst, M. (2005).Learning L2 Vocabulary through Extensive Reading: A Measurement Study. The Canadian Modern Language Review, 61, 355-382.

Horst, M., Cobb, T., Cobb, T., \& Meara, P. (1998). Beyond a clockwork orange: Acquiring second language vocabulary through reading. Reading in a Foreign Language, 11(2), 207-223.

Hulstijn J H \& Laufer B. (2001). Some empirical evidence for the Involvement Load Hypothesis in vocabulary acquisition. Language learning, 51, 539-558.

Hyde, T. S., \& Jenkins, J. J. (1973). Recall for words as a function of semantic, graphic, and syntactic orienting tasks. Journal of Verbal Learning and Verbal Behavior, 12(5), 471-480.

Kasahara, K. (2011). The effect of known-and-unknown word combinations on intentional vocabulary learning, System, 39(4), 491-499.

Kawauchi, Ch. (2005). Proficiency differences in CALL- Based vocabulary learning: The effectiveness of "PowerWords". Retrieved from http//:www.pdfebooksdownloads.com/vocabulary- proficiency.htm

Khonamri, F., \& Roostaee, S. (2014). The Impact of Task-based Extensive Reading on Lexical Collocation Knowledge of Intermediate EFL Learners. Procedia Social and Behavioral Sciences, 136, 265-270. http://doi.org/10.1016/j.sbspro.2014.05.326

Maghsoudi, M., Hassan, S., \& Mirkamali, F. (2014). The Impact of Different Tasks on Incidental Vocabulary Acquisition regarding Different Types of Dictionary. Procedia - Social and Behavioral Sciences, 98, 1056-1061. http://doi.org/10.1016/j.sbspro.2014.03.516

Mantyla, T. (2001). Incidental versus intentional memory. In N. J. Smelser \& P. B. Baltes (Eds.), International Encyclopedia of the Social and Behavioral Science (PP.7262-7265). Oxford: Pergamon.

Milton, J. (2009). Measuring Second Language Vocabulary Acquisition. Multilingual Matters, Bristol, England.

Nassaji, H. (2003). L2 vocabulary learning from context: strategies, knowledge sources, and their relationship with success in L2 lexical inferencing. TESOL Quarterly, 37, 645-673.

Nassaji, H. (2004). The relationship between depth of vocabulary knowledge and L2 learners' lexical inferencing strategy use and success. Canadian Modern Language Review, 61, 107-134.

Nation, I. S. P. (1990). Teaching and learning vocabulary. Boston: Heinle \& Heinle.

Nation, I. S. P. (2001). Learning vocabulary in another language. Cambridge: Cambridge University Press.

Nurweni, A., \& Read, J. (1999). The English vocabulary knowledge of Indonesian university students. English for Specific Purposes, 18, 161-175.

Paribakht, T.S., \& Wesche, M. (1996). Assessing second language vocabulary knowledge: depth vs. breadth. Canadian Modern Language Review, 53 (1), 1339.

Paribakht, T.S., \& Wesche, M. (1997). Vocabulary enhancement activities andreading for meaning in second language vocabulary acquisition. In J.Coady \& T. Huckin (Eds.), Second language vocabulary acquisition: A rationale for pedagogy (pp. 174199). New York: Cambridge University Press.

Prowse, P. (1999). Teacher's guide Cambridge English Readers. Cambridge: Cambridge University Press. 
Qian, D.D. (1998). Depth of vocabulary knowledge: assessing its role in adults, reading comprehension in English as a second language (Unpublished doctoral dissertation). University of Toronto, Ontario, Canada.

Qian, D.D. (1999). Assessing the roles of depth and breadth of vocabulary knowledge in reading comprehension. The Canadian Modern Language Review, 56, 282308.

Qian, D. D. (2002). Investigating the relationship between vocabulary knowledge and academic reading performance: An assessment perspective. Language learning, $52(3), 513-536$.

Rashidi, N., \& Piran, M. (2011). The Effect of Extensive and Intensive Reading on Iranian EFL Learners' Vocabulary Size and Depth. Journal of Language Teaching and Research, 2(2), 471-482.

Read, J. (1993). The development of a new measure of L2 vocabulary knowledge. Language Testing, 10, 355-371.

Read, J. (1998). Validating a test to measure depth of vocabulary knowledge. Validation in language assessment, 41-60.

Read, J. (2000). Assessing Vocabulary. Cambridge University Press, Cambridge, UK.

Read, J., (2004). Plumbing the depths: how should the construct of vocabulary knowledge be defined. In: Bogaards, P., Laufer, B. (Eds.), Vocabulary in a Second Language. John Benjamins Publishing Company, Amsterdam, pp. 209227.

Schmidt, R. (1994). Implicit learning and the cognitive unconscious: of artificial grammars and SLA. In N. C. Ellis (Eds.), Implicit and Explicit Learning of Languages (PP. 165-209). New York: Academic Press.

Schmidt, N., (2008). Review article: Instructed second language vocabulary learning. Language Teaching Research, 12, 329-363.

Tangitau, V. (1973). Intensive and extensive reading. TESL Reporter, 7(1), 7-9.

Wesche, M., Paribakht, T.S. (1996). Assessing second language vocabulary knowledge: depth versus breadth. Canadian Modern Language Review, 53, 13 40.

Winster, B., Hideki, S., \& Mariko, A. (2009). An Analysis of the Oxford Placement Test and the Michigan English Placement Test as L2 Proficiency. Hosei University Repository.

Wode, H. (1999). Incidental vocabulary acquisition in the foreign language classroom. Studies in Second Language Acquisition, 21(02), 243-258.

Yali, G. (2010). L2 Vocabulary acquisition through reading —incidental learning and intentional learning. Chinese Journal of Applied Linguistics, 33(1), 74-93.

Yamashita, J. (2008). Extensive reading and development of different aspects of L2 proficiency. System, 36, 661-672. 